\title{
Dança de rua: opção pela dignidade e compromisso social
}

Ana Cecília de Carvalho Reckziegel* Marco Paulo Stigger**

Resumo: este trabalho é parte dos resultados de uma pesquisa de caráter etnográfico que visou compreender o sentido atribuído à prática da dança de rua, por jovens moradores da periferia de Porto Alegre. Entre outras conclusões encontradas, identificou-se que a prática da dança, aliada aos princípios ideológicos colocados pelos elementos da cultura hip-hop e simbolizados pela atitude, caracteriza-se como um movimento estético-político que mobiliza os jovens, conduzindo-os a um engajamento político-social, com o objetivo de construir uma vida digna para si e resgatar crianças e adolescentes em situação de risco.

Palavras-chave: dança de rua, cultura, movimento social.

Este estudo é uma síntese da pesquisa desenvolvida no Programa de Pós-Graduação em Ciências do Movimento Humano, da Escola de Educação Física da Universidade Federal do Rio Grande do Sul, e relatada na dissertação de mestrado intitulada Dança de Rua: lazer e cultura jovem na Restinga. A pesquisa teve como principal objetivo compreender o sentido atribuído ao hip-hop pelos jovens da periferia de Porto Alegre, a partir da sua opção pela prática da dança de rua.

No intuito de evitar as visões macroscópicas, que tratam a cultura hip-hop e seus adeptos como desviantes ou como simples consumidores dos produtos do mercado cultural, balizado pelo modismo, optamos pela etnografia (Geertz, 1989), como possibilidade metodológica, pois a mesma possibilitaria dirigir a atenção para os aspectos particulares da cultura, ao invés de enfocar seus aspectos gerais. Os principais instrumentos utilizados para a coleta de dados foram a observação participante e a

* Mestre em Ciências do Movimento Humano pela Escola Superior de Educação Física.

Programa de Pós-Graduação em Ciências do Movimento Humano da Universidade Federal do Rio Grande do Sul.

** Doutor em Ciências do Desporto pela Universidade do Porto/Portugal.

Movimento, Porto Alegre, v. 11, n. 2, p.59-73, maio/agosto de 2005 
entrevista semi-estruturada, tendo como sujeitos do estudo o grupo Restinga Crew, do bairro Restinga, em Porto Alegre.'

Após a coleta e análise dos dados, definimos dois eixos de análise: a dança de rua como aprendizado e a dança de rua como lazer. Porém, com o objetivo de compreender o significado que a prática da dança tinha para o grupo, enquanto desenvolvíamos o trabalho, chamou-nos a atenção uma terceira linha de apreciação: a capacidade de mobilização do grupo, através da prática da dança, na busca de sua inclusão social, ou, nas palavras dos seus participantes, na busca de uma vida digna. Com este objetivo, o grupo se caracteriza como um movimento que desenvolve estratégias no âmbito interno e externo: internamente, no contexto do local e longe de qualquer política social por parte das instituições governamentais, começa a buscar sua inserção na comunidade, e conquistar visibilidade e respeito; externamente, ligando-se aos grupos dos diferentes elementos da cultura hiphop, inicia um movimento reivindicatório junto ao poder público local e nacional. ${ }^{2}$ É sobre essa inserção, sobretudo a local, e capacidade de mobilização social que vamos tratar neste artigo.

\section{O hip-hop}

A cultura hip-hop constitui-se pelo cruzamento de quatro elementos: o DJ, o MC, o break, e o grafite ${ }^{3}$ (Rose, 1997). Nasceu nos guetos pobres de negros e hispano-americanos dos EUA, na década de setenta, e acabou por difundir-se pelo mundo através dos meios de comunicação de massa. Tem origem nas Block Parties, ou festas de rua, nas quais os MCs incentivavam os participantes a se divertir pacificamente, iniciando assim a transmissão daqueles que podem ser considerados os princípios ideológicos da cultura (Rocha, Domenich e Casseano, 2001). Fradique (2003), identifica o hip-hop como um movimento cultural, e aponta como um de seus elementos indicadores a emergência de uma ideologia "[...] que tem como principal objetivo a criação de um conjunto de diretrizes para um modo de vida (de rua)

1 O grupo foi observado durante o ano de 2003.

2 O grupo participa das atividades da U2HT (União Rapper da Tinga), e do Fórum Municipal do hip-hop, instituído em agosto de 2004, e tem entre seus formadores organizações de hip-hop com atuação nacional.

3 Respectivamente, o Disc jóquei, o mestre de cerimônias, a dança praticada pelo b-boy e o grafiteiro.

Movimento, Porto Alegre, v. 11, n. 2, p.59-73, maio/agosto de 2005 
que se oponha à violência e que permita criar uma alternativa à rivalidade entre as gangs [...]" (op.cit., p. 107). ${ }^{4}$

Atualmente o fenômeno cultural conhecido como hip-hop ocupa um espaço significativo dentro do amplo panorama da cultura brasileira, e está presente nas mais diversas camadas sociais. Sua difusão em nosso país está ligada à chegada da cultura black e do movimento negro norte-americano, na década de 70, quando começam a ser difundidas as idéias do movimento black power nos bailes da época, caracterizando-se por uma postura radical e politizada (Herschmann, 2000).

Como exemplo temos os cantores de rap (rappers) que, com suas letras violentamente de protesto, denunciam a dura realidade das favelas e o tratamento recebido por essas populações tanto por parte dos governos, quanto por parte da polícia. Por isto, muitas vezes são acusados de incitar a população à violência e ao racismo (Herschmann, 2000). Esta postura e as ações dela provenientes e praticadas pelos seus adeptos, possibilita compreender o hip-hop como um movimento estético-político ( Silva, 1999), como um movimento social (Andrade, 1999), ou, ainda, como "redes conflituosas" (Meiucci apud Sposito, 1999, p.82).

Assim, o hip-hop se constrói como um estilo de vida marcado pelas roupas esportivas, pela linguagem verbal, e pela utilização dos produtos de consumo da indústria cultural, que são apropriados por estes jovens e se transformam em manifestações desta cultura. Mas, acima de tudo, o hip-hop é marcado pela atitude, "[...] termo que sintetiza a linha de conduta que o grupo espera de cada um" (Herschmann, 2000, p. 287), ou ainda a "[...] postura e en-gajamento político-social dos agentes multiplicadores desta cultura $[\ldots]^{\prime \prime}$.

A entrada do hip-hop no Brasil, no início dos anos 80, deuse por meio da dança, que logo ocupou as ruas e estações de metrô de São Paulo (Azevedo e Silva, 1999), e se manteve coerente com a sua origem nos bairros pobres de Nova York, há cerca de 30 anos, quando se solidificou como alternativa metafórica substitutiva para as brigas entre as gangues (Rocha,

4 Esta ideologia tem como referência África Bambaataa, ex-integrante de gangue de rua e fundador da organização Zulu Nation, que tem como princípios o conhecimento, a compreensão, a liberdade, a igualdade, a paz, o amor, a diversão e a superação do negativo pelo positivo (Louchard, 1999).

5 Ata da reunião do Fórum Municipal do hip-hop. 21/08/2004/Porto Alegre.

Movimento, Porto Alegre, v. 11, n. 2, p.59-73, maio/agosto de 2005 
Domenich e Casseano, 2001), deslocando os conflitos de rua para o plano artístico (Silva, 1999).

Também começando a partir da dança de rua, a cultura hiphop inicia em Porto Alegre por volta de 1983, com as rodas de bboys no centro da cidade (Gorczevski, 2000), e tinha o Bairro Restinga $^{6}$ como um pólo irradiador (Laitano, 2001). Na Restinga, a cultura chega a partir da cultura black, e mais especificamente do funk, que foi dando lugar ao estilo hip-hop. O final dos anos 80 e início dos 90 foi um momento de efervescência do hiphop na Restinga, quando surgiram muitos grupos, entre os quais o grupo Black Time, com o qual Juquinha - criador do grupo Restinga Crew - iniciou sua trajetória de b-boy.

\section{O Restinga Crew}

Criado há três anos, a partir de uma oficina de dança de rua coordenada pelo b-boy Juquinha, o Restinga Crew é composto por um núcleo fixo de oito jovens. Suas atividades se compõem pelo treinamento constante, pela criação e ensaio das coreografias do grupo e se complementa com o estudo dos outros elementos da cultura hip-hop. A sua prática se concretiza com as apresentações públicas das coreografias e com a participação do grupo em campeonatos de dança, chamados de rachas ou batalhas. ${ }^{7} \mathrm{O}$ grupo mantém no mínimo dois encontros semanais para os treinos ou ensaios, ${ }^{8}$ numa sala do Centro Comunitário da Restinga. Estes treinos são abertos a todos os interessados na prática da dança, e os iniciantes são recebidos e orientados por todos os integrantes do grupo que possuam mais tempo e experiência na dança. Portanto, o treino constitui-se também como oficina popular de dança de rua, que permanece aberta a todos os interessados.

\section{Estigmatização e liminaridade}

Nos estudos sobre o tema, chamou-nos a atenção a tendência que a opinião pública mostrava ao relacionar os jovens das camadas populares à violência urbana, transformando-os em

6 O Bairro Restinga é um bairro popular, distante $22 \mathrm{~km}$ do centro de Porto Alegre.

7 Os rachas ou batalhas são competições de dança entre b-boys ou grupos de dança de rua.

8 Assim denominados, seus encontros fixos, onde ocorre a ofina, são às quartas e sextas-feiras à noite.

Movimento, Porto Alegre, v. 11, n. 2, p.59-73, maio/agosto de 2005 
delinqüentes e gerando um processo de estigmatização. A noção de desvio utilizada pela mídia impressa e televisiva em nosso país era utilizada, sobretudo, para a criação da representação da juventude ligada ao movimento e estilos musicais da cultura hip-hop. A literatura especializada apontava que os jovens das periferias, em especial aqueles ligados ao hip-hop, vinham sofrendo esse processo de estigmatização (Herschmann, 2000).

A condição juvenil na periferia pobre dos centros urbanos possui uma natureza dupla. De um lado está a exclusão social, que "é decorrente das determinações advindas da situação de classe", de outro estão "as peculiaridades que decorrem da condição geracional, enquanto grupo de idade" e dizem respeito às características da condição juvenil, a saber: a busca da autonomia frente à família, e a transitoriedade (Sposito, 1994, p. 3).

A situação de liminaridade que perpassa a realidade da juventude pobre da periferia apresenta-se através da possibilidade de viver entre dois mundos. Um deles é o mundo do crime, ou do consumo e do tráfico de drogas, que oferece vantagens fáceis e imediatas. O outro é o mundo da legalidade, ou o mundo das instituições legitimadas pelas forças sociais - como o trabalho e a escola - que não apresenta alternativas eficazes de inclusão (Sposito, 1999, p. 84).

Para Gohn (1999), devido às alterações provocadas pelas políticas globalizantes, o mundo do trabalho vem exigindo novas habilidades aos indivíduos, como o domínio da comunicação em mais de um idioma, da linguagem das máquinas e de habilidades de gestão. Para a autora, esses pressupostos distorcem a realidade do mundo do trabalho, pois enfatizando a aquisição de novas habilidades "desloca a questão social do desemprego do âmbito das políticas governamentais [...] para os indivíduos, enquanto trabalhadores, caracterizando-os como mão-de-obra despreparada" (p. 95): enquanto pertencentes às camadas populares, eles são parias, "vagabundos pré-industriais" (op. cit., p. 97).

\section{Entre a ilegalidade e a legalidade:}

"ou tu é ladrão, ou tu é trabalhador"

É a este processo de estigmatização e à situação de liminaridade que estão expostos os jovens integrantes do Restinga Crew. Isto pode ser observado, quando percebemos que entre os integrantes do núcleo constituinte do Restinga Crew, apenas dois integrantes estudam. Os demais abandonaram os estudos por volta do primeiro ou segundo ano do segundo grau. Os motivos 
vão desde o desestímulo total até o desejo de dedicar-se apenas à dança, passando pelo perigo de estar na rua à noite. Mas o abandono dá-se principalmente devido à questão do trabalho: "eu tive que parar de estudar porque eu tinha que sustentar minha família [...] de noite eu tava muito cansado [...]. Eu era gari.[...] Eu chegava de noite em casa e estava tão cansado que não tinha vontade de ir para a aula (Lula).

Este depoimento reforça a idéia de que, embora a instituição escolar tenha evoluído na discussão e implantação de práticas pedagógicas e currículos que a aproximam da cultura das periferias, ${ }^{9}$ ao que parece, ainda não consegue mobilizar os jovens e estimulá-los a completar os estudos. Para Sposito (1993), este desestímulo dá-se porque, na situação de empobrecimento, os jovens não percebem melhorias de vida provenientes do trabalho em suas famílias; esta constatação leva-os a desconsiderar a função da escola na formação para o acesso ao mercado de trabalho. A autora percebe que há um deslocamento da situação da dupla atividade escola-trabalho, para uma única atividade de freqüentar apenas a escola, ou apenas o trabalho, e até uma "inatividade total" (op. cit., p. 13).

Fausto e Quiroga (2000) constataram a vinculação dos jovens a um diarismo que atende apenas às necessidades pessoais e familiares. Este é o quadro que encontramos entre os jovens do Restinga Crew, que em sua maioria conseguem manter-se através da cultura do "quebra-galho". A necessidade de sustentar a si e à sua família leva-os a aceitar todo tipo de serviço, sem possibilidade de escolha: "eu vou procurar o primeiro serviço que vier $[\ldots]$ Eu não escolho serviço [...]. O que pintar a gente estamos fazendo [...]. Eu não penso só em mim. Eu penso também na minha família" (Deivis).

No contexto que se apresenta, o sustento dos jovens se dá por meio de atividades que não são atraentes para eles, as quais, na maioria das vezes, são temporárias, como no caso de auxiliar de pedreiro, office-boy e gari, entre outros. Embora essas ocupações não sejam consideradas pelos jovens como indignas ou vexatórias, já foram classificadas como "nada assim muito importante" (Lula) e cansativas demais. Os comentários demonstram que diante das expectativas dos jovens sobre seu futuro, estas atividades não lhes propiciam satisfação pessoal.

9 Sobre hip-hop e educação, ver, entre outros, Sposito (1993, 1994, 1999), Andrade (1999), e Gustsack (2003).

Movimento, Porto Alegre, v. 11, n. 2, p.59-73, maio/agosto de 2005 
Com o abandono dos estudos, à mercê das leis do mercado e longe das políticas sociais governamentais, os jovens se vêem com o tempo totalmente livre, enquanto não "pinta um serviço" (Deivis). Isto os coloca numa situação de ter tempo disponível, o que, "se para uma parte representativa de pessoas [...] é como se fosse uma morte, para aqueles que têm todo o tempo sobrando a vida é morte [...] e o futuro parece ser sempre uma projeção sem sentido" (Diógenes, 1998, p. 46). ${ }^{10}$

No caso dos participantes do Restinga Crew, ter tempo demais sobrando se apresenta como o momento do perigo, em que a situação de liminaridade entre "ser ladrão ou ser trabalhador" aparece:

Porque assim, ó, na vida tu tem que escolher. Ou tu éladrão. Se tuéladrão tu tem que ser ladrão mesmo, e aí o que é que vai acontecer? Tu vai morrer. Se tu é trabalhador tu vai trabalhar e vai ter que viver com o teu salário e tentar fazero melhor possível [...] alguns escolhem isso, alguns escolhem ir por um caminho melhor possivel [...] alguns escolhem isso, alguns escolhem ir por um caminho
mais fácil, que é $o$ vender drogas e ter que estar se escondendo sempre da polícia [...] E outros escolhem o mais difícil, mas que compensa muito mais, que te dá toda uma dignidade [...] (Juquinha).

\section{O hip-hop e o processo de conscientização social e política}

Dentre os elementos da cultura hip-hop, aquele que mais chamou a atenção dos integrantes do Restinga Crew, antes de aderirem à prática da dança, foi o rap. Para eles, as letras de rap "passam alguma coisa", uma mensagem que os faz refletir sobre sua realidade, e contribuem para desencadear um processo de conscientização social e política.

Tanto no rap como nos demais elementos da cultura hiphop, é fundamental elaborar "uma mensagem pessoal" (Silva, 1999, p. 31). Esta mensagem pessoal está ligada à situação de exclusão vivida pelos jovens das periferias pobres do Brasil afora, e dá-se através de uma comunicação de igual para igual. O fundamento do rap é a experiência social de seus praticantes (Sposito, 1993). Para Tella (1999) e cabe ao rapper comunicar de forma clara e acessível as mensagens colocadas, para tentar "ampliar a consciência de uma parcela da juventude negra" (p.59), transmitir sua mensagem para o maior número de pessoas pos-

10 Grifos nossos

Movimento, Porto Alegre, v. 11, n. 2, p.59-73, maio/agosto de 2005 
sível, e "constituir-se numa alternativa de informação e conhecimento" (p. 63). O fato de antes de começarem a dançar já ouvirem rap dava-se justamente porque este lhes transmitia idéias importantes, e desvelava seu universo social, como a questão da sua situação de pobreza, auto-estima e da necessidade de lutar contra a sociedade que lhes provoca privações, na busca pelos seus direitos, porque, segundo eles, "a sociedade dá, mas ela também tira".

A identificação dos jovens da Restinga com a ideologia construída na origem do sistema cultural hip-hop é imediata, pois os contextos de vida desses jovens são similares àqueles. Lá ou aqui, a situação é análoga, por isso sua identificação com a cultura e suas expressões artísticas, vista como forma de comunicar ao mundo sua realidade e sua luta pelos direitos que os jovens compreendem que lhes são negados. O discurso ideológico da cultura, ${ }^{11}$ que transita pelos seus quatro elementos, é apropriado localmente, difundido nas letras de rap, e faz com que as idéias passem a ser assimiladas e praticadas pelos integrantes do Restinga Crew. Esta assimilação vai se dando aos poucos, a partir de sua inserção na cultura, e vai provocar a mobilização do grupo em busca de sua inclusão social.

Ao lado do rap, a motivação para iniciarem a prática da dança também se deu entre os participantes do grupo Restinga Crew pelo contato com grupos de sua própria comunidade ou por intermédio de amigos. Ao iniciar a prática da dança, o jovem é motivado apenas pela satisfação que esta lhe proporciona, mas, aos poucos, ao receber e buscar informação, dá-se conta de que a dança é uma das expressões que constituem um sistema cultural, o hip-hop. Nesta trajetória é possível perceber três momentos que se justapõem.

O primeiro momento inicia com a motivação do jovem pela dança, por intermédio de um amigo. Nesta fase a prática tem como único objetivo o divertimento, e a fruição das vantagens de saber dançar bem o estilo b-boy nas festas, principalmente, para "ganhar as gurias". Este momento se caracteriza também por uma dedicação intensa pela dança, com o objetivo de aprender a fazer os passos mais difíceis. E o período de vencer a vergonha e a dificuldade de aprender os passos. O segundo mo-

11 Ideologia que tem origem nas idéias de África Bambaataa, conforme explanação anterior.

Movimento, Porto Alegre, v. 11, n. 2, p.59-73, maio/agosto de 2005 
mento ocorre a partir da permanência do jovem na oficina, quando começa a ter êxito em seu treinamento, a dominar os passos, e começa a descobrir que a dança faz parte de uma cultura maior.

As informações sobre a cultura são transmitidas principalmente através do contato com outros grupos ou b-boys, e circulam através de uma rede de relações construída dentro do próprio bairro e no contato com praticantes de outros bairros (Laitano, 2001). Entre os jovens, a circulação de informações tem como conseqüência a noção de que não basta apenas saber dançar mas que é preciso saber o que é a dança, sua origem e sua história: "tem que ter qualidade [...] e tem que ter informação correta e conhecimento correto para desenvolver a dança [...] Tem que saber a história: "bah, meu o quê que é hip-hop, o quê que é rap" [...] tem gente que entra dentro da cultura e não sabe nem o que está fazendo" (Deivis).

É nesta fase que o jovem começa a tomar conhecimento sobre a cultura, quando os princípios ideológicos transmitidos por ela são incorporados pelos praticantes e passam a reger o comportamento dos jovens dentro e fora do grupo. Entre os integrantes do Restinga Crew, a compreensão do que seja a atitude se apresenta de maneira e em momentos variados. Em sua entrevista alguns participantes esclarecem o momento em que passaram a compreender o que é atitude:

Eu acho que a gente começou a ter atitude quando a gente começou a entendero que era a vida, eu acho, a vida na vila [...] a gente viu amigos que tiveram atitudes erradas e que acabaram se dando mal, então a gente teve que optar por uma coisa diferente [. ] nãoé específico da cultura. Eu acho que é um termo que ele é específico da vida. Na tua vida tu tem que ter atitude, tem que ser um cara de ação, mas que não prejudique ninguém, que te ajude e que possa ajudar os outros (Juquinha);

Eu, quando não estava dentro do movimento hip-hop, eu não ligava para essas coisas aí, atitude, essas coisas. Mas dentro do contexto da cultura hip-hop, quando a gente vai nos lugares, em primeirolugar é a atitude. Ter uma boa formação, tu ter uma postura boa, tu ter o que passar para as pessoas (Deivis).

Independentemente dos diferentes sentidos atribuídos a ela, o importante é que a atitude passa a balizar o modo de vida dos jovens e contribui para criar o ethos do grupo (Geertz, 1989). O jovem passa a refletir sobre a realidade socioeconômica em que está inserido e começa a abandonar sua prática de lazer anterior. A partir da geração do grupo, da tomada de consciência e do compromisso com a atitude, a adesão à cultura já é total. Os jovens demonstram a consciência de que aderem ou criam um estilo e começam a agir na defesa do mesmo. A partir do

Movimento, Porto Alegre, v. 11, n. 2, p.59-73, maio/agosto de 2005 
compromisso com a ideologia, se inserem em "um estilo [...]'cultura' - modo de vida que se reflete nas roupas, na performance do corpo, que se apresenta como uma ética, ou seja, um conjunto de normas e valores que orientam um programa de vida a ser aplicado quotidianamente e que permite dotar de sentido o diaa-dia" (Fradique, 2003, p. 107).

Este é terceiro momento, nele os jovens estão transformados, e vêem no hip-hop um de seus principais objetivos:

Desde que eu entrei dentro domovimento hip-hop eu mudei assim completamen-

te [...] a minha cabeça começou a mudar, eu comecei a aprender, a ver o que que é, né? E a minha cabeça começou a evoluir [...] porque o hip-hop me ajudou a evoluir. Eu pensava uma coisa, agora eu penso outra, eu tenho meus objetivos (Deivis);

O hip-hop não trabalha só dança [...]. Ele tente te mostrar o caminho [...]. O hip-hop ajuda a resgatar várias pessoas, ensina, que educa [...]. Com a nossa arte, com a nossa cultura, a gente tenta resgatar o pessoal da periferia, que talvez não teve a mesma chance que a gente teve de conhecer e de optar por uma coisa boa (Juquinha).

Desta forma, os jovens passam a se considerar como participantes da construção dessa história e responsáveis pela sua continuidade, e tomam para si a função de mensageiros da cultura, de multiplicadores. Assumem, espontaneamente, um compromisso com o social, por acreditarem que sua arte possibilita resgatar crianças e adolescentes em situação de risco.

\section{A dança como projeto de vida: a opção pela dignidade e o compromisso com o social}

Para os jovens, assumir este compromisso com o social, a partir do compromisso com a atitude, lhes dá a dignidade almejada. A partir da consciência adquirida através da cultura, os jovens tentam encaminhar a outros para a oficina, para " $[\ldots]$ não deixar esse pessoal com o tempo livre para fazer coisa errada [...] se é para ele estar num local onde ele possa fazer alguma coisa que possa prejudicar a ele e a outras pessoas, que ele fique com a gente, na sala, treinando" (Juquinha).

O resgate, então, é ocupar o tempo livre, o tempo perigoso, que não é preenchido nem pela escola, e nem pelo trabalho, mas que o hip-hop, com as inúmeras qualidades percebidas pelos jovens, é capaz de preencher. Isto se dá primeiro no próprio grupo, através de sua adesão à cultura e ocupação de seu tempo

Morimento, Porto Alegre, v. 11, n. 2, p.59-73, maio/agosto de 2005 
livre. Dá-se igualmente, pelo comportamento exemplar, calcado na atitude, e dá-se também pela transmissão da ideologia do hip-hop. Nesse sentido, alguns integrantes do grupo se identificam como militantes.

Eu digo assim, militante, porque a gente está ali com uma função[...].Eu acho que em primeiro lugar a gente tem que tentar pregar a paz para as pessoas [...] E depois tentar buscar a conscientização das pessoas. Eo hip-hop já luta contra qualquer tipo de preconceito, tanto racial quanto social [... ]. Quando eu canto, eu tento passar aquilo que eu vejo, assim nas ruas [... J Já na dança também, é uma forma de protesto. Por isso que a gente dança também (Deivis).

A militância se concretiza através das oficinas, com as idéias que nelas vão sendo transmitidas, e das apresentações públicas do grupo, que na grande maioria são efetuadas sem nenhum tipo de remuneraçãa. O grupo faz questão de se apresentar, justamente porque as apresentações também são consideradas como um canal de comunicação da cultura e de seus benefícios.

Desta forma, no sentido atribuído pelos seus participantes, a opção dos jovens integrantes do Restinga Crew, pela dança de rua, vem rompendo com o determinismo de um contexto socioeconômico desfavorável e apontando novos caminhos, transformando aquela que seria sua opção de lazer em um novo projeto para suas vidas.

Este projeto começa a se construir quando optam pela prática da dança e se concretiza quando decidem dar continuidade a ela. A dança é, para eles, uma alternativa de subsistência pessoal e uma possibilidade de transformar seu meio, a partir do resgate de outros jovens em situacão de liminaridade, à qual eles mesmos estiveram expostos. Eles assumem uma "conduta organizada para atingir finalidades específicas" (Velho, 1999, p. 40) ao manterem sua prática, ao ministrar oficinas e ao difundir a cultura hip-hop. Isto se apresenta para os jovens como um campo de possibilidades, como um "espaço para a formulação e implementação de projetos" (ibidem), dentro do qual seus projetos individuais convergem e se transformam em um projeto coletivo. Para esses jovens, o hip-hop auxilia na construção da sua cidadania e, portanto, de uma vida digna.

\section{Considerações finais}

Ao dedicarem seu tempo livre às atividades de lazer, na busca pelo divertimento, os jovens do Restinga Crew encontram o hip-hop. Ao optarem pela dança e formarem o grupo, iniciam um processo de socialização que acaba por substituir aquele que

Movimento, Porto Alegre, v. 11, n. 2, p.59-73, maio/agosto de 2005 
deveria ser vivenciado na escola e no trabalho. Desta forma o hip-hop cumpre aquela que é sua tarefa central: "atingir a consciência da juventude" e "criar esferas alternativas de agrupamentos" (Diógenes, 1998, p. 134). Reunidos pela dança em uma nova "alternativa de agrupamento", os jovens b-boys da Restinga começam a tomar consciência de sua realidade social, a tentar agir sobre ela e a ela resistir.

O nosso rap aqui, com a dança, ele é mais de protesto mesmo, e de mostrar aí para o pessoal que só porqueé pobre ele não tem que aceitar tudo oqueéoferecido, né? Que a gente tem que lutar pelos nossos direitos, e tem que reivindicar tudo que a gente acha que é nosso [...]. O nosso lance aqui é voltado mais para o social (Juquinha).

A noção de um "nós", impressa na fala acima, nos dá a dimensão da força deste agrupamento. Dentro dele, apoiado pelos companheiros, o jovem encontra segurança para optar pelo caminho mais difícil, mas que é visto por eles como aquele que é capaz de lhes dar "toda uma dignidade". Ao mesmo tempo, encontra segurança para recusar o que lhe é oferecido "só porque é pobre" e para almejar um futuro que não seja "uma projeção sem sentido". Os jovens optam por viver pacificamente, no mundo da legalidade, o qual precisará ajustar-se às suas expectativas. Na situação de liminaridade, vivida pelos jovens, a opção por uma forma pacífica de viver, ao invés da vida do crime e da violência, não deve ser compreendida como comodismo e resignação, mas como uma forma de resistência.

Esta forma de resistência foi constatada por Herschmann (2000), que, enquanto percebia o processo de estigmatização ao qual a juventude pobre ligada ao hip-hop era exposta, também constatava uma reação por parte daquela juventude, a partir de uma forte ideologia contra o racismo e a exclusão social.

Diógenes faz a mesma constatação ao estudar grupos semelhantes em Fortaleza. Para a autora, o movimento hip-hop daquela cidade assume um caráter instrumental e político, e é utilizado como tática de enfrentamento das desigualdades entre ricos e pobres. Porém, ao invés de se manifestar através da violência, o jovem manifesta-se através do "impacto 'conscientizador' da palavra" (1998, p. 132-10).

Assim, vemos que, a partir de sua experiência de vida e de sua necessidade de construir um sentido para a mesma, os jovens do Restinga Crew se relacionam com o entorno em busca de caminhos possíveis, e se deparam com uma nova opção, a cultura hip-hop, a qual passa a ser considerada por eles como

Movimento, Porto Alegre, v. 11, n. 2, p.59-73, maio/agosto de 2005 
uma alternativa. Ao optar pela dança, o grupo inicia um diálogo entre o global e o local e, deste diálogo, resulta a re-contextualização da cultura hip-hop e sua utilização para construir suas identidades, seus laços sociais e agir sobre seu meio, para que este, através de seu próprio esforço, se ajuste às suas expectativas.

\begin{abstract}
Street dance: a choice for dignity and social commitment

Abstract: This work is part of a research of ethnographic character that aimed to understand the meaning attributed to the practice of street dancing by young residents of the periphery of Porto Alegre. Among other conclusions, it was identified that the practice of dancing, among with ideological principles set by elements of the hip-hop culture and symbolized by the attitude, leading to a political and social engagement, with the purpose of building a worthy life for self and rescue children and adolescents in risk situation.
\end{abstract}

Keywords: street dance, culture, social engagement.

\title{
Danza de calle: opción por la dignidad y compromiso
} social

Resumen: Este trabajo es parte de los resultados de una investigación de carácter etnográfica que visó comprender el sentido atribuido a la práctica de la danza de calle, por jovenes residentes de la periferia de Porto Alegre. Entre otras conclusiones encontradas, se identifico que la práctica de la danza, aliada a los principios ideológicos colocados por los elementos de la cultura hip-hop y simbolizados por la actitud, se caracterizan con un movimiento estético-político que moviliza los jovenes, conduciéndolos a un posicionamiento político-social, con el objetivo de construir una vida digna para si y rescatar niños y adolescentes en situación de riesgo.

Palabras-clave: danza de calle, cultura, movimiento social.

Movimento, Porto Alegre, v. 11, n. 2, p.59-73, maio/agosto de 2005 


\section{Referências}

ANDRADE, Elaine. Hip-Hop: Movimento negro juvenil.In: ANDRADE, Elaine N. de (org.). Rap e educação, rap é educação. São Paulo: Summus, p. 83-92, 1999.

AZEVEDO, Amailton Magno Grillu e da SILVA, Salloma Salomão Jovino. Os sons que vêm das ruas. In: ANDRADE, Elaine N. de (org.). Rap e educação, rap é educação. São Paulo: Summus, p. 65-81, 1999.

DIÓGENES, Glória.Cartografias da violência. Gangues, galeras e o movimento Hip-Hop. São Paulo: Annablume; Fortaleza: Secretaria da Cultura e Desporto, 1998 .

DUARTE, Geni Rosa. A Arte na(da) periferia: sobre... vivências. In: ANDRADE, Elaine N. de (org.). Rap e educação, rap é educação. São Paulo: Summus, p. 1322, 1999.

FAUSTO NETO, Ana Maria; QUIROGA, Consuelo. Juventude urbana pobre: manifestações públicas e leituras sociais. In: PEREIRA, Carlos A. Messeder et al.. Linguagens da violência. Rio de Janeiro: Rocco, p. 221-235, 2000.

FRADIQUE, Teresa. Fixar o movimento nas margens do rio: duas experiências de construção de um objeto de estudo em terreno urbano em Portugal. In: VELHO, Gilberto e KUSCHNIR, Karina (orgs.). Pesquisas urbanas. desafios do trabalho antropológico. Rio de janeiro: Jorge Zahar p. 90-117, 2003.

GEERTZ, Clifford. Uma Descrição Densa: Por uma Teoria Interpretativa da Cultura. In: A interpretação das culturas. Rio de Janeiro: Koogan, p.13-41, 1989.

GOHN, Maria da Glória. Educação não-formal e cultura política. Impacto sobre o associativismo do terceiro setor. São Paulo: Cortez, 1999.

GORCZEVSKI, Deisimer. O hip-hop e a (in)visibilidade no cenário midiático. Dissertação de Mestrado do Programa de Pós-Graduação em Ciências da Comunicação do Centro de Ciências da Comunicação, Universidade do Vale do Rio dos Sinos, 2002.

GUSTSACK, Felipe. Hip-Hop. Educabilidades e traços culturais em movimento. Tese de Doutorado em Educação. Programa de Pós-Graduação da Faculdade de Educação, UFRGS, 2003.

HERSCHMANN, Micael. Ofunk e o hip-hop invadem a cena. Rio de Janeiro: UFRJ,2000.

LAITANO, Gisele Santos. Os territórios, os lugares e a subjetividade: construindo a geograficidade pela escrita do movimento hip-hop, no Bairro Restinga, em Porto Alegre, RS. Dissertação de Mestrado da UFRGS, Instituto de Geociências, Programa de Pós-Graduação em Geografia, Porto Alegre, julho 2001.

LOUCHARD, Aimée. Raça Brasil. Jogo Rápido. Afrika Bambaataa. São Paulo: março de 1999

Movimento, Porto Alegre, v. 11, n. 2, p.59-73, maio/agosto de 2005 
ROCHA, DOMENICH E CASSEANO. Hip Hop. A periferia grita. São Paulo: Fundação Perseu Abramo, 2001.

ROSE, Trícia. Um estilo que ninguém segura: política, estilo e a cidade pósindustrial no Hip-Hop. Tradução de Valéria Lamego. In: HERSCHMANN, Micae (org.). Abalando os anos 90 - funk e hip-hop. Globalização, violência e estilo cultural. Rio de Janeiro: Rocco, p. 192-212, 1997.

SILVA, José Carlos da. Arte e educação: a experiência do movimento Hip-Hop paulistano. In: ANDRADE, Elaine N. de (org.). Rap e educação, rap é educação. São Paulo: Summus, p. 23-38, 1999.

SPOSITO, Marília Pontes. Violência coletiva, jovens e educação: dimensões do conflito social na cidade. N. 7 (dez. 1994), p. 121-145. Trabalho apresentado na $16^{\text {a }}$. Reunião Anual da ANPED, Cadernos da ANPED, Caxambu. Niterói, 1993.

A sociabilidade juvenil e a rua: novos conflitos e ação coletiva da cidade.Vol. 1, f. 23-45. Trabalho apresentado na 17ä. Reunião Anual da ANPED, Caxambu, setembro de 1994.

Algumas hipóteses sobre as relações entre movimentos sociais, juventude e educação. N. 13 (jan/mar. 2000), p. 73-95, 150. Trabalho apresentado na XXII Reunião Anual da ANPEd, Caxambu, Revista Brasileira de Educação, jan.abr, n 13. Belo Horizonte, 1999.

TELLA, Marco Aurélio Paz. Rap, memória e identidade. In: ANDRADE, Elaine N. de (org.). Rap e educação, rap é educação. São Paulo: Summus, p. 5563,1999 .

VELHO, Gilberto. Projeto e metamorfose: antropologia das sociedades contemporâneas. 2. ed. Rio de Janeiro: Zahar, 1999.

\author{
Data entrega:15.03.05 \\ Data parecer:11.04.05 \\ Ana Cecília Reckziege \\ Rua Livramento, 581/302 \\ Porto Alegre - Rio Grande do Su \\ CEP.: 90640-130$$
\text { e-mail: }
$$ \\ acreckziegel@cpovo.net \\ Marco Paulo Stigger \\ Escola de Educação Física \\ Departamento de Educação Física \\ Rua Felizardo, 750 \\ 90690-200 - Porto Alegre \\ e-mail: stigger@adufrgs.ufrgs.br
}

Movimento, Porto Alegre, v. 11, n. 2, p.59-73, maio/agosto de 2005 